\title{
The Transition to Electronic Communications Networks in the Secondary Treasury Market
}

\author{
Bruce Mizrach and Christopher J. Neely
}

\begin{abstract}
This article reviews the history of the recent shift to electronic trading in equity, foreign exchange, and fixed-income markets. The authors analyze a new data set: the eSpeed electronic Treasury network. They contrast the market microstructure of the eSpeed trading platform with the traditional voice-assisted networks that report through GovPX. The electronic market (eSpeed) has greater volume, smaller spreads, and a lower estimated trade impact than the voice market (GovPX). (JEL G14, G12, D4, C32)
\end{abstract}

Federal Reserve Bank of St. Louis Review, November/December 2006, 88(6), pp. 527-41.

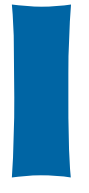

$\mathrm{n}$ the past 15 years, advances in information technology have revolutionized electronic trading-posting quotes, transacting, and confirming orders electronically. Electronic methods have grown to dominate trading in major asset markets, such as equities, foreign exchange, and most recently U.S. Treasuries.

The Securities and Exchange Commission (SEC) (2000) defines electronic communications networks (ECNs) as "electronic trading systems that automatically match buy and sell orders at specified prices." 1 ECNs have several advantages over other systems, such as open-outcry trading floors or telephone trading. First, ECNs permit users all over the world to trade, without regard to physical location. Second, ECNs permit the number of traders, the size of trades, or the asset to vary costlessly. Third, ECNs automate the processing and clearing of trading, reducing the risk of clearing errors and facilitating risk management (Bank for International Settlements [BIS], 2001).

1 One should not confuse ECNs, which offer firm prices and immediate execution, with other forms of trading that use electronic technology.
The advantages of ECNs are most evident in the markets for more liquid and homogenous assets. In contrast, assets whose trading requires more customization - that is, negotiation over quantities and settlement details-will benefit from human brokers. Barclay, Hendershott, and Kotz (2006) discuss the conditions under which voice brokers outperform ECNs in conveying complex information ("market color") during trading for lessliquid assets or nonstandard instruments.

By dramatically reducing the cost of trading for relatively liquid and homogeneous assets, electronic trading has facilitated portfolio management for institutional investors and banks. Rising volume has mirrored the fall in the cost of trading, enabling customers to rebalance portfolios more quickly, making them less risky.

This article scrutinizes a previously unexamined data set, the U.S. Treasury bond market data from the eSpeed ECN, founded by Cantor Fitzgerald and Co. We have a complete record of trades and quotes from eSpeed for 2004, and we contrast the ECN market with similar 1999 data from GovPX, a joint venture among voice brokers. Compared with GovPX, eSpeed exhibits much

Bruce Mizrach is an associate professor of economics at Rutgers University, and Christopher J. Neely is a research officer at the Federal Reserve Bank of St. Louis. The authors thank Bill Emmons, Michael Fleming, Ken Garbade, Laura Lipscomb, and Dan Thornton for helpful comments on preliminary drafts and Justin Hauke for outstanding research assistance.

(C) 2006, The Federal Reserve Bank of St. Louis. Articles may be reprinted, reproduced, published, distributed, displayed, and transmitted in their entirety if copyright notice, author name(s), and full citation are included. Abstracts, synopses, and other derivative works may be made only with prior written permission of the Federal Reserve Bank of St. Louis. 


\section{Mizrach and Neely}

lower spreads and a smaller impact on prices from order flow. A detailed understanding of market microstructure can contribute to better regulation and improvements to market architecture.

\section{STAGES OF THE TREASURY BOND MARKET}

The sale of Treasuries undergoes three distinct phases: primary, on-the-run, and off-the-run. Each of these three stages has a distinct market structure.

\section{The Primary Market}

In the first or primary stage, the U.S. Treasury auctions off debt to the public. Garbade and Ingber (2005) describe this process in detail. ${ }^{2}$ The

Treasury provides a predictable flow of auction information to "promote competitiveness by enhancing market transparencies" and to improve the size of offerings. Since August 8, 2002, the Treasury has made auction announcements (for all new securities) at 11:00 a.m. eastern time. There is also a stable schedule ${ }^{3}$ for auctions. For example, 3- and 6-month bills are auctioned weekly; 2 - and 5-year notes are auctioned monthly; 30-year bonds were reintroduced on February 9, 2006, after a 5year hiatus, and are auctioned in February and August each year.

A few days prior to the auction, the specific dollar amount (par value) of the securities to be auctioned is announced and the when-issued security market begins. The when-issued market continues until settlement of auction purchases. Nyborg and Sundaresan (1996) document that when-issued trading provides important information about auction prices prior to the auction and also permits market participants to reduce the risk they take in bidding. ${ }^{4}$

2 See the glossary for definitions of terms.

3 The Treasury auction schedule can be found at: www.treasury.gov/ offices/domestic-finance/debt-management/auctions/.

4 On August 20, 1998, the Treasury shortened the when-issued period for 13- and 26-week bill auctions. Similarly, the Treasury shortened the when-issued period by two days for 2-year notes, beginning with the August 2, 2002, auction. Fleming (2002) and Garbade and Ingber (2005) discuss the results of such changes in when-issued periods.
Bids for Treasury auctions can either be competitive bids by primary dealers or noncompetitive bids by firms and individuals. Firms and individuals can also competitively bid through brokers and primary dealers. Competitive bids specify a price to be bid and a quantity sought. In the recent past, there have been two types of auctions: multiple-price and single-price.

Garbade and Ingber (2005) discuss the transition from multiple-price auctions to single-price auctions. Historically (prior to 1992) multipleprice auctions were used to sell Treasury securities. In multiple-price auctions, the competitive bids were ranked to determine the highest yield that will sell all the Treasuries. The average yield for all accepted competitive bids is called the stop-out yield. First, all noncompetitive bids are satisfied at the stop-out yield and then the remainder of the auctioned securities are allocated to competitive bidders with the lowest bid yield (highest bid price). Competitive bids above the stop-out yield are not filled, whereas those at the stop-out yield may be only partially filled.

The Treasury began to experiment with singleprice auctions in 1992 for the 2- and 5-year notes (Garbade and Ingber, 2005). In this auction design, all securities are allocated to bidders at the price implied by the highest accepted yield. In October 1998, the Treasury adopted this procedure for all maturities, safeguarded by quantity restrictions on the amount a single bidder can purchase.

Upon completion of the auction, the most recently issued bill, note, or bond becomes onthe-run and the previous on-the-run issue goes off-the-run. Both on-the-run and off-the-run trading occurs in the secondary Treasury market. Secondary market participants are often divided into two parts: the sell side and the buy side. The primary securities dealers constitute the sell side, while the diverse group of final users of Treasury bonds constitutes the buy side. The buy side includes commercial and investment banks, insurance companies, financial firms, investors, and pension funds-those who use Treasuries for speculation, as well as for hedging real and financial risk. 


\section{Figure 1}

\section{Secondary Government Bond Market, 2005 Market Share}

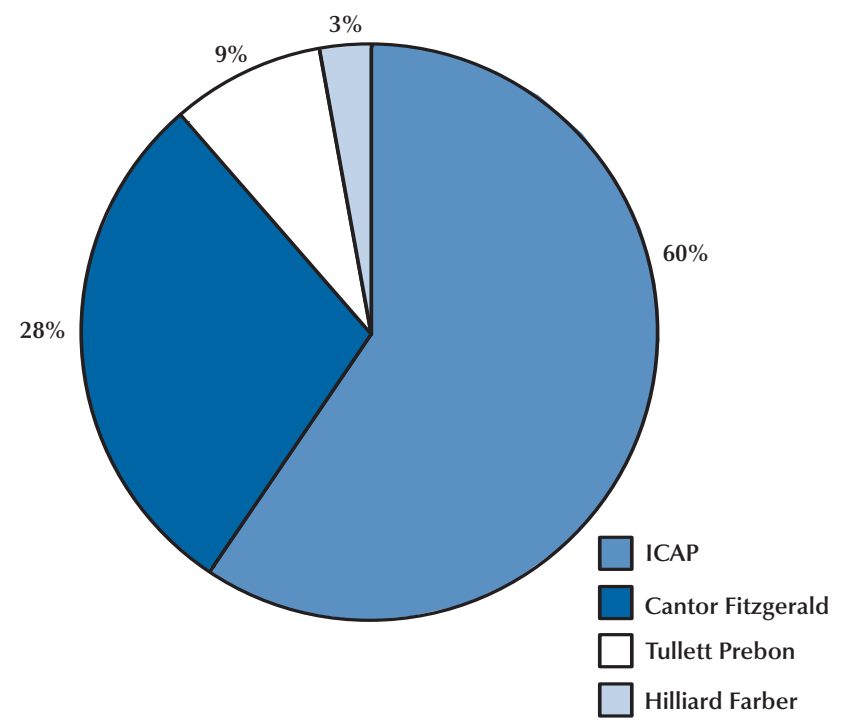

SOURCE: Federal Reserve Bank of New York primary dealer data, ICAP 2005 Annual Report, eSpeed Quarterly Report, and market estimates from www.espeed.com and www.cstplc.com (Tullett Prebon).

\section{The Overall Secondary Market}

It is difficult to get primary source data for all secondary market transactions, therefore we will use market-share ${ }^{5}$ estimates made by the Federal Reserve and industry participants. Figure 1 shows that, in 2005, two large interdealer brokerage (IDB) firms dominate the overall secondary market: ICAP PLC, with a 60 percent market share, and Cantor Fitzgerald, with 28 percent. Both of these firms trade a large array of fixed-income financial instruments, including swaps, and mortgagebacked and agency securities, using both electronic and voice-brokered systems. We describe these two firms and their purely electronic Treasury platforms in greater detail in the next sec-

5 Mizrach and Neely (2005) explore a related concept known as information share. This is a statistical measure of where (in which market) price discovery takes place. From 1995 to 1999, we found the spot and futures markets played nearly equal roles, with futures dominating after 1999.

\section{Figure 2}

\section{ECN Trading of On-the-Run Treasury Securities, 2005:Q3 Market Share}

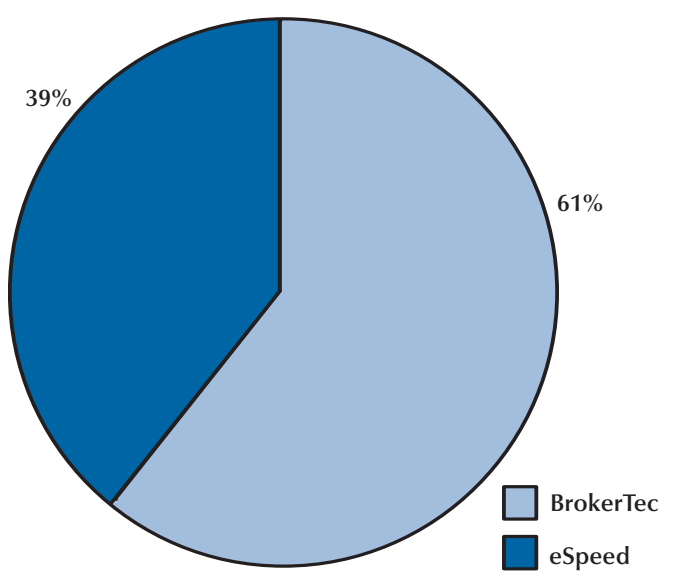

SOURCE: Federal Reserve Bank of New York primary dealer data, eSpeed and ICAP 2005 financials, and author's estimates.

tion. Tullett Prebon, ${ }^{6}$ with 9 percent, and Hilliard Farber \& Co., with 3 percent, complete the secondary Treasury market.

On- and off-the-run markets differ by volume and trading methods. We turn first to the more liquid on-the-run market.

On-the-Run. There is much more secondary volume in on-the-run securities than off-the-run securities, with the former representing 70 percent of all trading volume (Fabozzi and Fleming, 2005). Because of this liquidity difference, offthe-run securities trade at a higher yield (lower price) than on-the-run securities of similar maturity. The amount by which the off-the-run yield exceeds the on-the-run yield is known as the

${ }^{6}$ Collins Stewart Tullett PLC is an agglomeration of a number of prior firms: (i) Collins Stewart Ltd. was a London-based financial services firm founded in 1991; (ii) Tullett \& Riley was founded in 1971, originally focusing on foreign exchange; (iii) Tokyo Forex took a stake in Tullett in 1986, creating Tullett \& Tokyo; (iv) in 2000, Tullett \& Tokyo merged with Liberty Brokerage to create Tullett \& Tokyo Liberty; (v) Prebon was formed in 1990 following the merger of three leading London-based money broking businesses, Babcock \& Brown, Kirkland-Whittaker, and Fulton Prebon; (vi) Prebon's close business alliance with the Tokyo-based Yamane Tanshi provided its current title of Prebon Yamane. Collins Stewart acquired Tullett in March 2003 and Prebon in October 2004. The firm's IDB business uses the name Tullett Prebon. 


\section{Mizrach and Neely}

liquidity premium. Trading of benchmark (onthe-run) issues is commoditized, and nearly all of it has migrated to the electronic networks. ${ }^{7}$

Figure 2 shows market share estimates for the ECN portion of the on-the-run market in the third quarter of $2005 .^{8}$ We estimate that on-the-run trading for this quarter was $\$ 21.19$ trillion. ${ }^{9}$ In their financial filings, eSpeed reports transactions volumes of $\$ 8.014$ trillion during the quarter. We then estimate BrokerTec ECN volume of $\$ 12.29$ trillion. ${ }^{10}$ These figures imply on-the-run ECN market shares, 61 percent for BrokerTec and 39 percent for eSpeed, as reported in Figure 2, which are consistent with industry estimates for that time (Kutler, 2006). eSpeed reports that it has gained market share since the third quarter of 2005, however. ${ }^{11}$

We now turn to the more numerous but less actively traded off-the-run issues.

Off-the-Run. Off-the-run securities require more customization-that is, negotiation over quantities and settlement details-and thus benefit from human brokers. Although assets themselves don't change when they go off-therun, they do become more heterogeneous with respect to depth, the quantity the dealer is willing to sell at the bid or offer. Therefore they require more negotiation in trading. Barclay, Hendershott, and Kotz (2006) report that transaction volume falls by more than 90 percent, on average, once a bond goes off-the-run. There is a large number of issues-99 notes and 43 bonds as of February 2006-but, with each being relatively illiquid, most off-the-run trading occurs in traditional voice networks.

\footnotetext{
7 Commoditized securities are those that are undifferentiated and liquid and trade only on price. See the glossary for further definitions.

8 Electronic trading in fixed income refers to both electronically brokered, voice-assisted transactions and pure ECN trades. We focus only on the latter here.

9 Total Treasury market trading volume averaged $\$ 473$ billion per day or $\$ 30.27$ trillion for the whole quarter. Assuming 70 percent was on-the-run, we arrive at the $\$ 21.19$ trillion estimate.

${ }^{10}$ ICAP's BrokerTec reports a 58 percent overall secondary market share in their filings, and we assume the same market share in the on-the-run portion.

${ }^{11}$ Cantor Fitzgerald reported a market share gain since 2005:Q3 in a
} personal communication.
ESpeed does not compete with BrokerTec in off-the-run trading, but the voice-assisted part of Cantor Fitzgerald does compete with ICAP. Because neither firm breaks out their off-the-run voice-assisted trading from their overall figures, we cannot estimate a market share for off-the-run trading.

\section{THE GROWTH OF ELECTRONIC TRADING}

Compared with equity or foreign exchange markets, bond markets were slower to adopt electronic trading. The bond market is large and decentralized, such as the NASDAQ equity market or foreign exchange market, but has more varied assets-many types of bonds, maturities, coupons, strips, etc. Two boxed inserts in this article describe the growth of electronic trading in equity and foreign exchange markets. The greater complexity of trading in sundry instruments, each of which has less liquidity than large capitalization stocks or the major currencies, retarded the transition to electronic trading.

Electronic communications can play different roles in the trading process. For more than a decade, bond trading screens have displayed quotes from dealers that helped to initiate voice transactions. This section focuses on the completely electronic trading through ECNs. These ECNs permit dealers to post transactable prices and quantities and execute trades electronically.

Cantor Fitzgerald introduced the first ECN in bond markets, eSpeed, in 1999. A consortium of Wall Street firms, including Morgan Stanley and Goldman Sachs, launched a competitor, BrokerTec, the same year. BrokerTec began commercial operations in 2000. ICAP PLC, a global, London-based IDB, acquired BrokerTec in April 2003. On-therun trading is now almost completely electronic, with the market split roughly 60-40 between the two ECNs, as Figure 2 illustrates. While these ECNs (eSpeed and BrokerTec) have captured most bond market trading activity, voice brokerage systems are used for trading in less liquid assets or more complex deals. 


\section{History of Cantor Fitzgerald}

Bernie Cantor and John Fitzgerald founded the firm of Cantor Fitzgerald in 1945 to provide investment advice to wealthy individuals. Cantor Fitzgerald rose to prominence as a Wall Street bond market broker. Cantor's fortunes rose in 1972, when it bought a controlling interest in Telerate and began to post bond prices for its bond dealer clients through the Telerate computer network. Customers purchased the data streams and naturally directed business toward its source, Cantor. The strategy was so successful in generating trading volume that Cantor gained a "nearly monopolistic" bond market share (Zuckerman, Davis, and McGee, 2001). ${ }^{12}$ Rising federal government budget deficits in the 1980s aided Cantor's fortunes by greatly expanding the bond market. By the early 1990s, Cantor Fitzgerald had 20 to 25 percent of the IDB market (SEC, 1992).

In 1991, demands by the SEC and bond market dealers for greater transparency led to the formation of GovPX, a joint venture among five IDBs. ${ }^{13}$ Cantor was the only IDB that did not participate in GovPX. GovPX was established to provide realtime interdealer trade prices and volume for U.S. Treasury bonds. The information is made publicly available, distributed through the Internet and data vendors.

As electronic trading became commonplace in the equity and foreign exchange markets, Cantor followed suit by starting the first electronic brokerage system for bonds, eSpeed, in March 1999. Cantor subsequently spun off eSpeed in a December 1999 public offering, but retains a controlling interest. ESpeed Inc. is listed on the NASDAQ and trades under the symbol ESPD.

\footnotetext{
${ }^{12}$ Rust and Hall (2003) present a model to explain the differences in microstructure between markets. They motivate their paper by observing that Cantor Fitzgerald has been a successful market maker in the U.S. Treasury bond market, but such an outcomea single market maker-has not emerged in the market for steel.

${ }^{13}$ The original IDBs reporting to GovPX were Garvin Guy Butler, Liberty Brokerage, Hilliard Farber, RMJ, and Tullet \& Tokyo Securities. As the structure of the market changed, so did the brokers reporting to GovPX. Fleming (2003), which examines the period 1997-2000, listed GovPX coverage as including GarbanIntercapital, Hilliard Farber, and Tullett \& Tokyo Liberty. After ICAP's purchase of GovPX in January 2005, ICAP PLC was the only broker reporting through GovPX.
}

The terrorist attacks of September 11, 2001, struck Cantor particularly hard, destroying its offices in the World Trade Center and killing 658 employees. Despite this tragedy, eSpeed became one of the two dominant trading platforms in the IDB market for U.S. Treasuries.

\section{ICAP and BrokerTec}

Cantor was not alone in seeing the potential of an electronic IDB bond-trading system. In 1999, several other Wall Street firms, including Morgan Stanley Dean Witter \& Co. and Goldman Sachs Inc., founded BrokerTec Global LLC. ICAP is the product of a merger between Garban PLC and Intercapital PLC in September 1999; originally called Garban-Intercapital, the name was changed to ICAP in July 2001. ICAP is currently the world's largest IDB with revenues of $£ 794$ million, and operating profits of $£ 122.7$ million. The company trades publicly on the London Stock Exchange under the symbol IAP.

In February 2000, Garban-Intercapital launched the Electronic Trading Community (ETC), a hybrid voice/electronic brokering system for the Treasury market. They eventually struck alliances with Tullett \& Tokyo Liberty in November 2000 and SunGard in September 2001.

ICAP realized that it needed to grow its ECN business and bought BrokerTec's Treasury platform in April 2003 for \$185.9 million. The U.S. Department of Justice approved the purchase after restructuring commission agreements between the pre-merger entities (Department of Justice, 2003). ICAP has used the BrokerTec platform to form partnerships similar to the one with MarketAxess in March 2004 (Wall Street \& Technology, 2004). ICAP also acquired the data provider GovPX Inc., in January 2005.

\section{Recent Competition}

ESpeed briefly had a dominant 70 percent share in on-the-run trading, but BrokerTec gained market share with lower transactions costs. Cantor Fitzgerald filed a lawsuit alleging patent infringement on eSpeed's trading systems. The case, filed in January 2003, was dismissed in February 2005 by a Delaware court. 


\section{ELECTRONIC TRADING IN EQUITY MARKETS}

The equity markets were the first to embrace electronic trading. Over-the-counter stocks have traded electronically at least since the creation of the National Association of Security Dealers (NASD) automated quote (NASDAQ) system in 1971. NASDAQ was a dealer market without a central trading floor. It was a distant second competitor to the floor-based New York Stock Exchange (NYSE).

The Philadelphia Stock Exchange was one of the first floor exchanges in the United States to introduce electronic trading with the PACE (Philadelphia Automated Communication and Execution) System in 1975. PACE permitted two-party trading from anywhere in the world but allowed for only limited information flow. Purely electronic limit order books began with Instinet in 1979. Instinet provided interdealer equity trading in both NYSE and NASDAQ securities. ${ }^{1}$

Despite the early adoption of this technology, U.S. equity markets tended to lag behind foreign markets in establishing electronic markets. ECNs were created in Toronto in 1977, Tokyo in 1982, Paris in 1986, Australia in 1990, Germany in 1991, Israel in 1991, Mexico in 1993, and Switzerland in 1995 (Economides and Schwartz, 1995).

The Chicago Board of Trade (CBOT) moved the equity futures and options markets significantly toward electronic trading with the successful introduction of GLOBEX, in 1994. The CBOT followed this effort with GLOBEX2, in 1998, which permitted round-the-clock trading.

Christie and Schultz (1994) triggered a watershed in electronic trading by finding NASDAQ market makers to be colluding over spreads. Following this discovery, in 1997, the SEC allowed electronic communication networks (ECNs) or alternative trading systems (ATS) to compete with NASDAQ dealers on an equal footing. This legal deregulation sparked a surge in electronic trading in U.S. equity markets. However, in moving to electronic trading through independent ECNs, the U.S. equity markets have differed from those in the rest of the world, where existing exchanges have largely developed electronic trading.

By 2004, ECNs had grabbed a dominant market share of equity trading. In 2005, both NASDAQ and the NYSE initiated mergers with their major electronic competitors. NASDAQ completed its merger with Instinet in 2005 and the NYSE with Archipelago in March 2006. Even with major changes and new electronic competition, the market has reorganized as a duopoly.

Although NASDAQ dealers held only a 35 percent market share in October 2005, this figure understates the market power of the for-profit NASDAQ. The combined market share of NASDAQ's own anonymous trading facility SIZE, and the Brut and Instinet ECNs that NASDAQ has acquired, gives this ECN more than three-quarters of the market (Mizrach, 2005).

Going forward, it appears that a hybrid market model with floor-based, open-outcry trading will co-exist with electronic trading both through limit order books and the NASDAQ dealer structure. Both NASDAQ and NYSE are now able to trade securities listed on the rival exchange. In August 2006, NASDAQ handled 12.5 percent of the volume in NYSE-listed securities, while the NYSE processed 21.3 percent of the trading in NASDAQ listings.

1 A limit order is a request to buy or sell a security at a specific price. Market orders are buy/sell orders that are to be executed immediately, at current market prices. 


\section{ELECTRONIC TRADING IN EQUITY MARKETS, cont'd}

\section{Figure B1}

\section{ECN Share in Over-the-Counter Equities}

\section{A. Trading Volume of NASDAQ-Listed Shares}

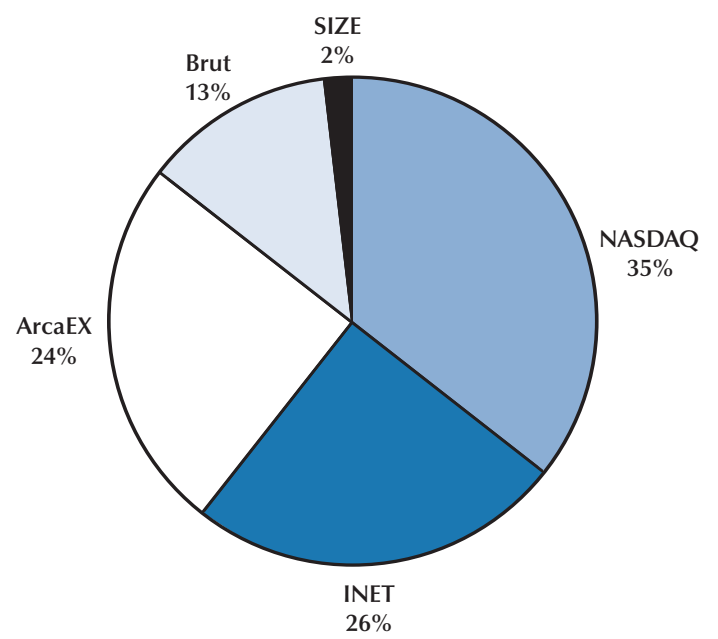

NOTE: Brut is the Brass Utility ECN, ArcaEX is the Archipelago ECN, INET is Instinet, and SIZE is the NASDAQ anonymous trading facility. All other NASDAQ market markers are grouped into the NASDAQ 35 percent share. NASDAQ acquired BRUT in September 2004 and Instinet in December 2005.

SOURCE: Securities Industry News, Bloomberg, Instinet, Archipelago, and NASDAQ.

B. ECN's Share of Trading Volume in NASDAQ-Listed Shares

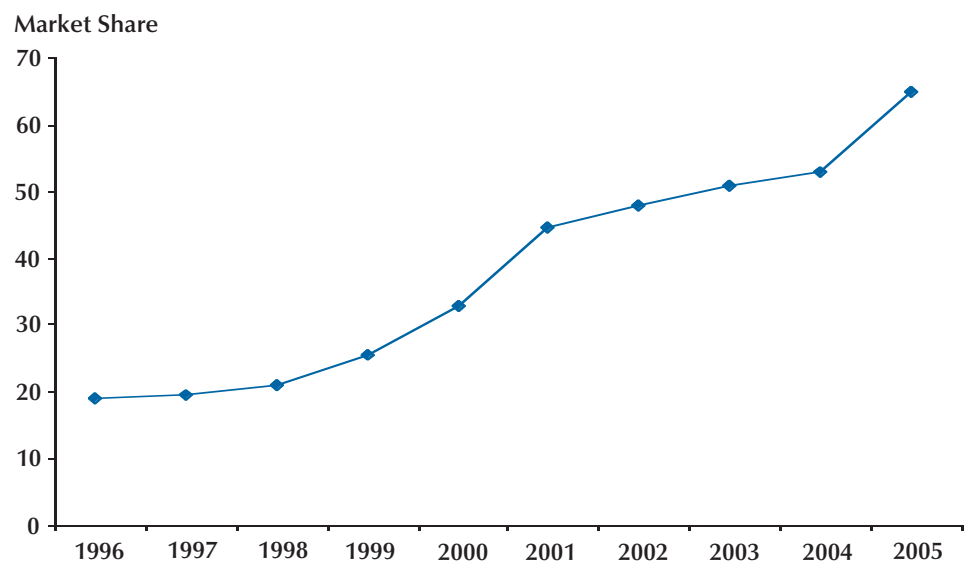

NOTE: The figure shows the growth of ECN trading since they entered the NASDAQ quote display in 1996. SOURCE: Smith (2002), Merrill Lynch, Bloomberg, Instinet, Archipelago, and NASDAQ. 


\section{ELECTRONIC TRADING IN FOREIGN EXCHANGE MARKETS}

The foreign exchange market is made up of customers, dealers, and IDBs. Customers are firms or individuals who buy or sell foreign exchange to hedge risk associated with business activities or balance sheet exposure, to manage investment portfolios, or to import/export goods and services. Hedge funds and pension funds, for example, frequently use the foreign exchange market to improve their investment performance. Corporations might buy foreign exchange to purchase needed intermediate goods from foreign suppliers. Dealers, who typically work for banks, stand ready to "make a market" - that is, to quote prices at which they are ready to buy or sell foreign exchange. Dealers wish to profit from the spread between the prices at which they buy and sell, as well as to take calculated intraday positions in currencies to profit from short-term expected changes in exchange rates. Dealers carefully manage their currency positions—especially overnight—to reduce their exposure to adverse exchange rate movements. Therefore, most trading in the foreign exchange market is between dealers who are seeking to manage their currency exposure. Interdealer brokers exist to facilitate this trading by matching buyers and sellers of foreign exchange. They do not take positions of their own.

Until the early 1990s, all foreign exchange trading was conducted via telephone. Reuters introduced the Reuters Market Data Service (RMDS) in February 1981, which permitted the exchange of information over computer screens, but did not allow actual trading. Reuters Dealing 2000-1 replaced RMDS in 1989. The new system facilitated direct trading that used to take place over the telephone (Rime, 2003).

Reuters continued to lead electronic trading in foreign exchange when it launched Dealing 2000-2 (D2000-2) in 1992. This network brokered trades between ex ante anonymous parties. Competitors soon followed, however. Minex launched an automated trading system in April 1993 and a consortium of large banks-ABN-AMRO, Bank of America, Barclays, Chemical, Citibank, Citicorp, Commerzbank, Credit Suisse, Lehman Brothers, Midland, J.P. Morgan, NatWest, Swiss Bankcorp, and Union Bank of Switzerland-followed suit by creating Electronic Broking Service (EBS) in April 1993, which later bought out Minex in 1996 (Chaboud and Weinberg, 2002).

For the first few years of their existence, the electronic trading systems' (ETS) share of foreign exchange trading grew slowly. But the figure shows that electronic trading was clearly the dominant method of operation in the interdealer market by the late 1990s. Chaboud and Weinberg (2002) estimate the share of interdealer trading volume executed through electronic platforms to be over 60 percent by 2001 . Voice trading remained important for customers and for less-liquid currencies. This is consistent with the general observation that electronic trading has its greatest advantages in the most liquid markets for homogenous assets.

Reuters and EBS remain the principal ETSs in the interdealer foreign exchange market as of early 2006. The latest incarnation of the Reuters network is called D3000. EBS has the foremost market share in trading in the two largest currency pairs, the euro-dollar and dollar-yen, while Reuters has a leading share in British pound currency pairs and the major market shares in a broader selection of exchange rates, including emerging market rates. 


\section{ELECTRONIC TRADING IN FOREIGN EXCHANGE MARKETS, cont'd}

In recent years, the already large foreign exchange market has continued to grow. The Bank for International Settlements reports that foreign exchange trading volume grew by 36 percent, from 2001 to 2004 (BIS, 2005). Some of this growth has occurred on exchanges such as the Chicago Mercantile Exchange, which currently handles only a very small proportion of the foreign exchange market. In the midst of this expansion, the dealer market has consolidated; more trading is done by fewer and larger banks.

These large banks have their own (bank-specific) electronic trading platforms that allow direct bank-customer trading. The three banks with the highest volumes are Deutsche Bank, UBS, and Barclays, according to Kimbell, Newby, and Skalinder (2005). But there are now a number of smaller electronic networks that facilitate transactions between customers and dealers (e.g., FX All, FX Connect, and Currenex) and between customers without dealers (e.g., OANDA, HotSpot FX, IG Markets, FXDealerDirect, DealStation, ChoiceFX, Deal4Free Forex, GFT’s DealbookFX, GCI, IFX Markets, and Grain Capital). These ECNs enable non-bank actors-such as hedge funds-to trade at prices that are very close to those enjoyed by the largest banks.

\section{Figure B2}

\section{Electronic Trading in Foreign Exchange Markets \\ Market Share of ECNs in Foreign Exchange Market Transactions}

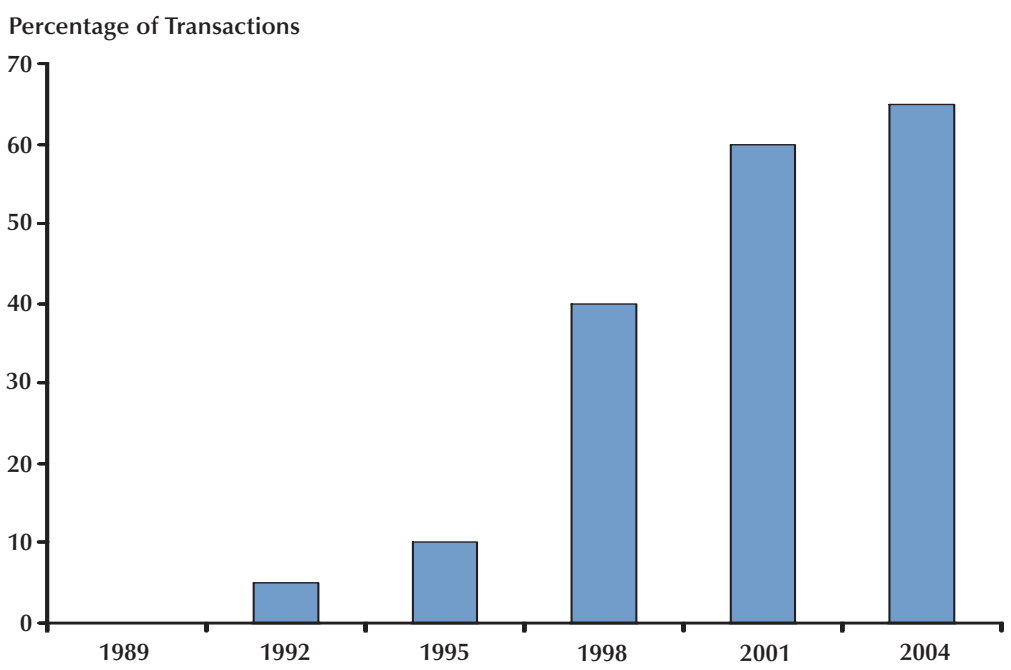

NOTE: Precise estimates of electronic foreign exchange broking systems' market share are difficult to come by because of the foreign exchange market's decentralized nature. The BIS (2004) estimates the 2004 number and states that the share increased slightly in that year by an unspecified amount.

SOURCE: Estimates for 1989-2001 are from Chaboud and Weinberg (2002). The BIS provides the 2004 number. 


\section{Mizrach and Neely}

Transactions costs have fallen dramatically over the past decade. Fleming (1997) reports fees paid by the trade initiator of $\$ 39$ per $\$ 1$ million of bonds in the voice-brokered GovPX markets. By 2005, these fees had fallen by more than 90 percent to $\$ 2.50$ on eSpeed and $\$ 2.00$ on BrokerTec for the best customers (Kruger, 2005).

ESpeed's price improvement facility, a tool that allowed traders to offer prices between the quotes, reportedly also hurt them in the marketplace (Computer Business Review, 2005). The price improvement system proved complex and unpopular with customers. Quantity, rather than price negotiation, had been standard in the industry in the days of voice brokerage, and eSpeed eliminated the price-improvement tool in January 2005. These changes seem to have stabilized a duopoly in ECN on-the-run trading with the market split 60-40 between BrokerTec and eSpeed, respectively.

\section{DATA SOURCES AND ANALYSIS}

To study trading activity, spreads, and price impact, we rely on two publicly available historical transactions databases. The first is GovPX, which consolidated voice-brokered interdealer quotes and trades from Garban-Intercapital, Hilliard Farber, and Tullett \& Tokyo Liberty during our sample period of 1999. Fleming (2003) describes the characteristics of liquidity in this market in the period from 1997 to 2000. Our second source is the eSpeed ECN, which recently began to offer a transactions database.

Both the GovPX and eSpeed data sets have their limitations. GovPX does not provide a reliable indicator of transactions after March 2001. The market share of voice-brokered trading has also substantially diminished since 1999. The eSpeed data set is from 2004, contains only onthe-run securities, and includes transactions but no quotes.

\section{Trading Activity}

Trading volume continues to grow in the government bond market much faster than the supply of Treasuries. The marketable federal debt held by the public grew from $\$ 3.64$ trillion in fiscal year 1999 to $\$ 4.31$ trillion in fiscal year 2004. ${ }^{14}$ Figure 3 shows the average daily trading volume in Treasuries from 1994 to 2005. Since its 1999 nadir of under $\$ 200$ billion per day, the average volume of such transactions by primary dealers has almost tripled to nearly $\$ 575$ billion.

GovPX trading volume declined markedly after 1999 as ECNs, such as eSpeed and BrokerTec, began to attract business. Because the GovPX trade volume data become very thin after 1999, this paper will contrast GovPX data from 1999-the last year in which voice-brokered trading predominated-with eSpeed data from 2004.

While we omit the exact figures to protect confidentiality, the data show a dramatic increase in trading volume between 1999 and 2004, which dwarfs the tripling of the government bond market over the same period. It seems likely that the lower cost of trading through ECNs has facilitated much higher turnover, attracting new participants to the Treasury market. More than 50 percent of bids and offers on BrokerTec are now from algorithmic trading firms (Safarik, 2005) rather than the primary dealers.

\section{Spreads}

A standard measure of liquidity is the bid/ask spread. Dealers in the Treasury market post quotes, along with depth, to both buy and sell Treasuries. A combination of inventory and adverse selection costs explains the existence of spreads in the interdealer market. The inventory component is the cost of keeping a ready supply of securities for sale. The adverse selection component is due to the risk that the dealer's counterparty has private information about future price changes, which could lead to losses for the dealer. Adverse selection is less of a problem in the Treasury market (which is driven by publicly available information) than in equity markets (in which private

\footnotetext{
${ }^{14}$ The debt figures are available at www.publicdebt.treas.gov/opd/ opdpdodt.htm. Ironically, market participants and the Federal Reserve were concerned about running out of Treasuries just a few years ago when federal budget surpluses were growing. Alan Greenspan (2001) testified in January 2001: "At zero debt, the continuing unified budget surpluses currently projected imply a major accumulation of private assets by the federal government."
} 


\section{Figure 3}

\section{Average Daily Treasury Volume}

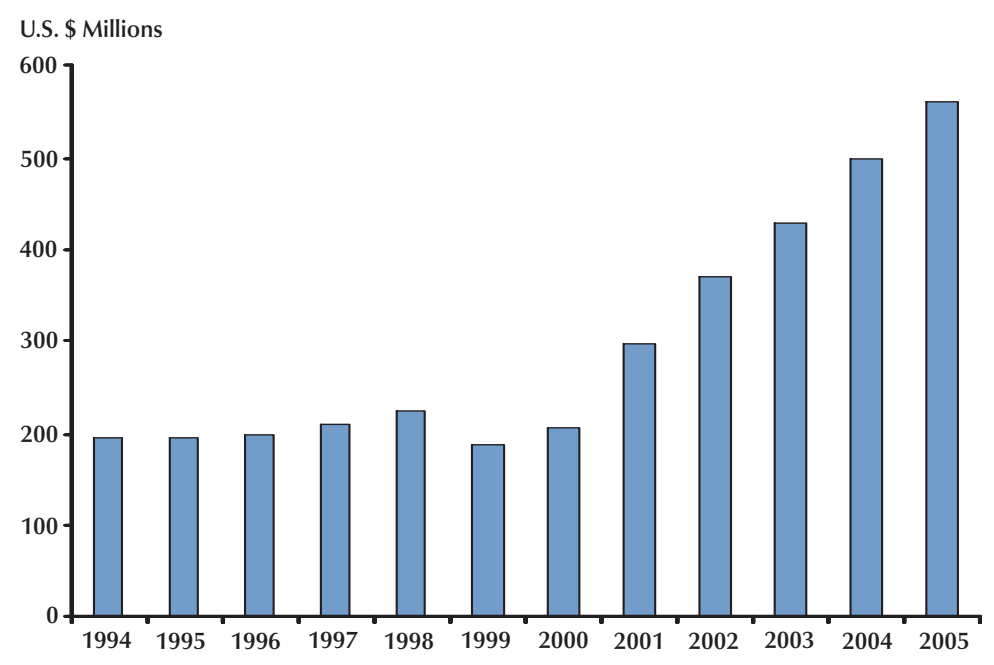

NOTE: The figure displays average daily volume of U.S. Treasury securities primary dealer transactions, by year. SOURCE: Federal Reserve Bank of New York primary dealer data.

information is more important). We measure this markup for the GovPX data in 1999 and the eSpeed data in 2004.

The most basic measure of the bid/ask spread is the quoted spread. The quoted spread is the gap between lowest ask price, $p_{t}^{a}$, and the highest bid, $p_{t}^{b}{ }^{15}$ It is computed in percentage terms to compare spreads across securities and over time:

$$
s_{t}^{q}=100 \times \frac{\left(p_{t}^{a}-p_{t}^{b}\right)}{p_{t}^{a}} .
$$

Unfortunately, the eSpeed database does not include posted bid and ask prices, and we must compute an alternative measure based on transactions.

A commonly used procedure, first proposed by Thompson and Waller (1988), is to measure the spread for day $t$ with the mean absolute change in the transactions prices:

\footnotetext{
${ }^{15}$ Many transactions take place within the quoted spread, though. GovPX provides a workup facility to increase the transaction size but not change the price. Until January 2005, the eSpeed network provided an explicit mechanism for trading between the bid and ask, a process known as price improvement.
}

$$
S_{t}^{T W}=\sum_{i=i}^{T}\left|p_{i}-p_{i-1}\right|^{+} / T^{+},
$$

where $T^{+}$is the number of transactions in which the price changes on day $t$. The correlation between quoted spreads and the transactions measure is 0.99 in the GovPX data.

Table 1 summarizes the differences in Thompson and Waller (1988) bid-ask spreads as on-the-run trading moved to ECNs.

The GovPX voice market spreads average 0.8344 basis points for the 2-year note in 1999, compared with 0.2053 for the eSpeed ECN quotes in 2004, a reduction of 75 percent. The reduction is similar for other maturities: 0.8834 basis points in the 5 -year, or 76 percent; 1.7167 basis points in the 10-year, or 82 percent; and, finally, 4.2622 basis points in the 30 -year, or 78 percent. These substantial declines are statistically and economically significant.

\section{MARKET IMPACT}

A purchase or a sale of an asset might influence prices either through inventory effects or by 
Table 1

Spreads in the Voice and ECN Markets

\begin{tabular}{lcccc} 
& GovPX & eSpeed & $\Delta$ Spread & Percent change \\
\hline 2-year & 0.8344 & 0.2053 & -0.6291 & -75 \\
5-year & 1.1572 & 0.2738 & -0.8834 & -76 \\
10-year & 2.0986 & 0.3819 & -1.7167 & -82 \\
30-year & 5.4484 & 1.1862 & -4.2622 & -78
\end{tabular}

NOTE: The GovPX estimates are from 1999, and the eSpeed estimates are from 2004. The spread units are in basis points (hundredths of a percent).

\section{Table 2}

\section{Market Impact Estimates for the Voice and ECN Markets}

\begin{tabular}{lcc} 
& GovPX & eSpeed \\
\hline 2-year & 0.4235 & 0.2321 \\
5-year & 0.9368 & 0.1709 \\
10-year & 0.9066 & 0.1850 \\
30-year & 2.2936 & 0.2749
\end{tabular}

NOTE: These are the 15-minute cumulative market impact effects for the January 1999 GovPX database and for the January 2004 eSpeed transactions based on the VAR analysis shown by equations (3) and (4). The units are in basis points (hundredths of a percent).

revealing private information about fundamentals to other market participants. One would like to know how much trades impact prices. Price impact increases the cost of large trades, and such costs are often larger than brokerage commissions and spreads. This section examines the interaction between trades and quotes using the vector autoregressive (VAR) system methods that Hasbrouck (1991) introduced.

Hasbrouck proposed to study intraday price formation with a standard bivariate VAR model. Time $t$ here is measured in 1-minute intervals. Let $r_{t}$ be the percentage change in the transaction price. $x_{t}^{0}$ is the sum of signed trade indicators $(+1$ for buyer initiated, -1 for seller initiated) over minute $t$. Fortunately, both data sets directly indicate trade initiation as a "hit" -1 or a "take" $+1 .{ }^{16}$
The bivariate VAR assumes that causality flows from trade initiation to returns by permitting $r_{t}$ to depend on the contemporaneous value for $x_{t}^{0}$, but not allowing $x_{t}^{0}$ to depend on contemporaneous $r_{t}$. The quote revision model is specified as follows:

$$
\begin{gathered}
r_{t}=a_{r, 0}+\sum_{i=1}^{5} a_{r, i} r_{t-i}+\sum_{i=0}^{15} b_{r, i} x_{t-i}^{0}+\varepsilon_{r, t}, \\
x_{t}^{0}=a_{x, 0}+\sum_{i=1}^{5} a_{x, i} r_{t-i}+\sum_{i=1}^{15} b_{x, i} x_{t-i}^{0}+\varepsilon_{x, t} .
\end{gathered}
$$

We estimate two versions of the VAR model for each instrument: One version uses GovPX data from 8:20 to 15:00 each day in January 1999, and the other version uses similar eSpeed data from January 2004. The original number of observations varied from instrument to instrument before aggregating to one-minute frequency. For example there were $17,127,62,175,75,791$, and 19,706 observations for the 2-, 5-, 10-, and 30-year bonds for the Cantor data. After aggregating to one-minute returns there were 8,000 observations for the 20 trading days in the Cantor data and 7,600 observations for the 19 trading days in the GovPX data. To allow comparison with other more-recent market impact studies, such as Cohen and Shin (2003), we include 15 lags of the signed trades. ${ }^{17}$

\footnotetext{
${ }^{16}$ In microstructure databases, this inference is usually determined by distance from the quote midpoint.

${ }^{17}$ Given the potentially unusual distribution of the order flow variable, $x_{t}^{0}$, we considered nonlinear specifications-products of leads and lags-but they do not enter the VAR significantly or change substantially the market impact estimates. There does not appear to be any significant nonlinearity in the dependent variable.
} 
Our estimates show that trade indicators are positively autocorrelated and highly predictable. In other words, buyer- (seller-) initiated trades reliably tend to follow buyer- (seller-) initiated trades. As one might expect from simple versions of the efficient markets hypothesis, returns are not very predictable, except through contemporaneous orders. That is, net buyer- (seller-) initiated trades are associated with contemporaneous price increases (decreases).

The market impact of the trade can be measured by the dynamic effect on subsequent trade prices. The impact grows over time, generally stabilizing after about 15 minutes. We report 15minute impact estimates in Table 2 for the 2-, 5-, 10-, and 30-year bonds. GovPX estimates for January 1999 are reported in the first column, and eSpeed estimates for January 2004 are reported in the second column. The coefficients are in basis points (hundredths of a percent).

The smallest GovPX market impact is for the 2-year note. Nonetheless, a one-unit (\$1 million) buy order still moves trade prices by 0.4235 basis points, nearly double the eSpeed impact for the same issue. The relative market impact is inversely related to the relative volumes of the two markets. For the other issues, the GovPX market impact is five to eight times as large, with the latter figure for the illiquid 30-year Treasury. On average, the eSpeed market impact is 73.6 percent lower than that of GovPX.

We believe that market impact is the most comprehensive measure of market quality, reflecting spreads, depths, and trading volume. The eSpeed ECN seems to illustrate that electronic trading in the secondary Treasury market benefits market participants by reducing spreads and transactions costs.

\section{CONCLUSION}

This article has reviewed the growth of ECNs in equity, foreign exchange, and the U.S. Treasury markets. The growth of such ECNs has enabled firms and individuals to trade and rebalance their portfolios at much lower cost, thereby enabling them to reduce the risk to which they are exposed.
In particular, this article has examined the growth of electronic competition in the secondary market for U.S. Treasury bonds. The eSpeed and BrokerTec ECNs have captured virtually the entire market for the on-the-run Treasuries. This paper has studied transactions from eSpeed for 2004, a data set that has not yet been explored in the literature, and documented improvements over the earlier voice-assisted technology. The eSpeed ECN has greater volume, smaller spreads, and a lower estimated impact of a trade. Lower spreads can benefit smaller traders by lowering their costs of portfolio rebalancing. A smaller market impact ensures that institutional investors get similar benefits.

\section{REFERENCES}

Bank for International Settlements, Committee on the Global Financial System. The Implications of Electronic Trading in Financial Markets. 2001.

Bank for International Settlements, Committee on the Global Financial System. Triennial Central Bank Survey: Foreign Exchange and Derivatives Market Activity in 2004. March 2005.

Barclay, Michael J.; Hendershott, Terrence and Kotz, Kenneth. "Automation Versus Intermediation: Evidence from Treasuries Going Off the Run." Forthcoming in the Journal of Finance, October 2006.

Chaboud, Alain and Weinberg, Steven. "Foreign Exchange Markets in the 1990s: Intraday Market Volatility and the Growth of Electronic Trading." Bank of International Settlements Papers, 2002, 12(Part 8), pp. 138-47.

Christie, William and Schultz, Paul. "Why Do NASDAQ Market Makers Avoid Odd-Eighth Quotes?" Journal of Finance, December 1994, 49(5), pp. 181340.

Cohen, Benjamin H. and Shin, Hyun Song. "Positive Feedback Trading Under Stress: Evidence From the U.S. Treasury Securities Market.” BIS Working Paper No. 122, Bank for International Settlements, January 2003. 


\section{Mizrach and Neely}

Computer Business Review. "eSpeed to Remove Price Improvement Feature.” January 7, 2005.

Department of Justice. "ICAP PLC and BrokerTec LLC Restructure Deal after Justice Department Raises Antitrust Objections." Department of Justice Press Release, April 22, 2003.

Economides, Nicholas and Robert A. Schwartz. "Electronic Call Market Trading." Journal of Portfolio Management, Spring 1995, 21(3), pp. 10-18.

Fabozzi, Frank J. and Michael J. Fleming. "U.S. Treasury and Agency Securities,” in Frank J. Fabozzi, ed., The Handbook of Fixed Income Securities, 7th Edition. New York: McGraw Hill, 2005.

Fleming, Michael J. “The Round-the-Clock Market for U.S. Treasury Securities.” Federal Reserve Bank of New York Economic Policy Review, July 1997, 3(2), pp. 9-32.

Fleming, Michael J. “Are Larger Treasury Issues More Liquid? Evidence from Bill Reopenings,” Journal of Money, Credit, and Banking, August 2002, 34(3), pp. 707-35.

Fleming, Michael J. "Measuring Treasury Market Liquidity.” Federal Reserve Bank of New York Economic Policy Review, September 2003, 9(3), pp. 83-108.

Garbade, Kenneth D. and Ingber, Jeffrey F. "The Treasury Auction Process: Objectives, Structure, and Recent Adaptations." Federal Reserve Bank of New York Current Issues in Economics and Finance, February 2005, 11(2), pp. 1-11.

Greenspan, Alan. "Outlook for the Federal Budget and Implications for Fiscal Policy.” Testimony before the Committee on the Budget, U.S. Senate, January 25, 2001.

Hasbrouck, Joel. "Measuring the Information Content of Stock Trades.” Journal of Finance, March 1991, 46(1), pp. 179-207.

Kimbell, Deborah; Newby, Andrew, and Skalinder, David. "The Big Get Bigger-But Is It for the Best?" Euromoney, May 2005, 36(433), pp. 74-85.
Kruger, Daniel. “On the Run.” Forbes, August 15, 2005.

Kutler, Jeffrey. "Cantor Spin-Offs Prepare Integrated Platform for Repos.” Securities Industry News, January 16, 2006, p. 11.

Mizrach, Bruce. "Does SIZE Matter: Liquidity Provision By The Nasdaq Anonymous Trading Facility.” Rutgers University Working Paper, December 2005.

Mizrach, Bruce and Neely, Christopher J. "The Microstructure of Bond Market Tatonnement." Federal Reserve Bank of St. Louis Working Paper No. 2005-70, November 2005.

Nyborg, Kjell G. and Sundaresan, Suresh.

"Discriminatory versus Uniform Treasury Auctions: Evidence from When-Issued Transactions." Journal of Financial Economics, September 1996, 42(1), pp. 63-104.

Rime, Dagfinn. "New Electronic Trading Systems in Foreign Exchange Markets,” in Derek C. Jones, ed., New Economy Handbook. Chapter 21. New York: Elsevier, 2003, pp. 469-504.

Rust, John and Hall, George. "Middlemen versus Market Makers: A Theory of Competitive Exchange." Journal of Political Economy, April 2003, 111(2), pp. 353-403.

Safarik, Daniel. "Fixed Income Meets the Black Box." Wall Street \& Technology, October 24, 2005, pp. A7.

Securities and Exchange Commission, Department of the Treasury, Board of Governors Federal of the Reserve System. Joint Report on the Government Securities Market. 1992.

Securities and Exchange Commission and Department of the Treasury. Special Study: Electronic Communication Networks and After-Hours Trading. 2000.

Smith, G.W. "ECN Market Share Analysis: Fourth Quarter 2001.” Equity Research, J.P. Morgan Securities Inc., January 30, 2002.

Thompson, Sarahelen. R., and Waller, Mark L. “The 
Intraday Variability Of Soybean Futures Prices: Information and Trading Effects." Review of Futures Markets, 1988, 7(1), pp. 110-126.

Wall Street \& Technology. Electronic-Trading

Newsflashes, March 29, 2004.
Zuckerman, G.; Davis, A. and McGee, S. "Before and After: Why Cantor Fitzgerald Can Never Re-create What It Once Was." Wall Street Journal, October 26, 2001, p. A1.

\section{GLOSSARY}

Agency securities are issued by institutions established by the U.S. government, such as the Student Loan Marketing Association (Sallie Mae). Such institutions were created to lower borrowing costs in favored sectors of the economy.

Algorithmic trading is the practice of automatically transacting based on a quantitative model.

A broker is a firm that matches buyers and sellers in financial transactions. Brokerage firms in bond markets do not trade for their own account. An interdealer broker (IDB) is an intermediary providing trading services to hedge funds, institutions, and other dealers. IDBs handle the majority of Treasury securities transactions in the secondary market.

A commoditized security has been altered to increase its liquidity, making it an undifferentiated product traded solely on price.

Depth is the quantity the dealer is willing to sell at the bid or offer.

Electronic communications networks (ECNs) are electronic trading systems that automatically match buy and sell orders at specified prices.

A limit order is a request to buy or sell a security at a specific price. Market orders are buy/sell orders that are to be executed immediately, at current market prices.

A mortgage-backed security is a bond whose payoff is backed by the payments on a pool of mortgages, such as those issued by Freddie Mac.

On-the-run refers to the most recently auctioned Treasury security of a particular maturity. After the next auction, the other bonds go off-the-run.

The quoted spread is the gap between lowest ask price and the highest bid.

Trading in on-the-run and off-the-run securities makes up the secondary Treasury market.

Strips are portions of securities that have been separated into different assets. U.S. Treasury bonds, for example, are often split into principal and interest components and each can be separately owned.

Such division permits the construction of zero-coupon bonds. STRIPS stands for "Separate Trading of Registered Interest and Principal Securities.”

Parties to an interest rate swap exchange interest payments on a notional principal amount. Typically, one party pays a fixed interest rate, while the other party pays a floating rate.

When-issued bonds are those Treasuries whose auctions have been announced but that have not yet been delivered. 
